\title{
Silvia Disegni, Les poètes journalistes au temps de Baudelaire
}

\section{Cecilia Torelli}

\section{Q OpenEdition \\ 1 Journals}

\section{Edizione digitale}

URL: http://journals.openedition.org/studifrancesi/30607

DOI: $10.4000 /$ studifrancesi.30607

ISSN: 2421-5856

\section{Editore}

Rosenberg \& Sellier

\section{Edizione cartacea}

Data di pubblicazione: 1 avril 2006

Paginazione: 184

ISSN: 0039-2944

Notizia bibliografica digitale

Cecilia Torelli, «Silvia Disegni, Les poètes journalistes au temps de Baudelaire», Studi Francesi [Online], 148 (XLX | I) | 2006, online dal 30 novembre 2015, consultato il 21 avril 2021. URL: http:// journals.openedition.org/studifrancesi/30607 ; DOI: https://doi.org/10.4000/studifrancesi.30607

Questo documento è stato generato automaticamente il 21 avril 2021.

\section{(c) (i) $\odot$}

Studi Francesi è distribuita con Licenza Creative Commons Attribuzione - Non commerciale - Non opere derivate 4.0 Internazionale. 


\title{
Silvia Disegni, Les poètes journalistes au temps de Baudelaire
}

\author{
Cecilia Torelli
}

\section{NOTIZIA}

SILVIA DISEGNI, Les poètes journalistes au temps de Baudelaire, " Recherches \& Travaux », Poésie et journalisme au XIX ${ }^{e}$ siècle en France et en Italie, n. 65, 2004, pp. 83-98.

1 L'A. si propone di analizzare la figura del poeta giornalista che si afferma in maniera preponderante nel XIX secolo, quando molti poeti, soprattutto per motivi economici, sono costretti a mettere la loro arte al servizio del giornalismo. Numerosi quotidiani, tra i quali "Le Corsaire-Satan", "La Presse", "Le Présent", "Le Figaro" accolgono Baudelaire, Banville, Champfleury; in riviste come "L'Artiste"e la "Revue fantaisiste" si ritrovano le firme di Gautier, Nerval, Champfleury, Banville, Baudelaire, per citare solo alcuni nomi. L'A. intende dimostrare che la stampa, con i suoi meccanismi, le sue tematiche e la sua scrittura, ha influito in modo decisivo sulla nascita di forme poetiche moderne nelle quali il soggetto lirico, la percezione del reale e il linguaggio subiscono un profondo rinnovamento. 